\title{
KOMPOSISI NUTRISI BEBERAPA BAHAN BAKU LOKAL DAN NILAI KECERNAAN PROTEINNYA PADA IKAN KERAPU BEBEK, Cromileptes altivelis
}

\author{
Asda Laining") dan Rachmansyah")
}

\begin{abstract}
ABSTRAK
Analisis komposisi nutrisi beberapa bahan baku lokal dan penentuan nilai kecernaan proteinnya pada ikan kerapu bebek, Cromileptes altivelis telah dilakukan untuk mendapatkan informasi dasar mengenai kualitas bahan tersebut dalam upaya pemanfaatannya pada budi daya ikan. Bahan baku yang diuji adalah bahan sumber hewani yang terdiri atas tepung ikan tembang, tepung ikan komersial, tepung kepala udang, tepung darah, dan tepung silase darah dengan asam formiat serta tepung silase darah dengan asam propionat. Bahan sumber nabati yaitu tepung kedelai, bungkil kelapa sawit, dan dedak. Kadar protein, lemak, dan energi dari bahan sumber hewani antara 44,7\%-87,2\%; 0,2\%-9,9\%; 2.500-5.333 $\mathrm{kal} / \mathrm{g}$ dan untuk bahan sumber nabati berturut-turut antara 10,6\%-41,0\%; 11,9\%-18,4\%; dan 3.141-4.310 kal/g. Asam amino esensial dari tepung darah meningkat setelah diolah dalam bentuk silase darah baik dengan menggunakan asam formiat 3\% maupun dengan asam propionat 3\%. Nilai kecernaan bahan kering dan protein dari bahan baku tersebut berturut-turut adalah: tepung kepala udang $58,5 \%$ dan $78,01 \%$; tepung kedelai $54,8 \%$ dan $67,2 \%$; tepung bungkil kelapa sawit $45,3 \%$ dan $80,5 \%$; tepung darah $48,1 \%$ dan $55,2 \%$; tepung silase A (asam formiat $3 \%$ ) $67,9 \%$ dan $87,5 \%$; tepung silase darah B (asam propionat 3\%) 61,7\% dan 84,2\%; tepung ikan tembang $87,2 \%$ dan $92,5 \%$; tepung ikan komersial $59,1 \%$ dan $82,4 \%$; serta dedak $22,2 \%$ dan $59,5 \%$. Data yang diperoleh menunjukkan bahwa, bahan baku lokal tersebut cukup potensial digunakan dalam pakan ikan baik sebagai sumber protein maupun sebagai sumber lemak dan energi.
\end{abstract}

ABSRACT: Chemical composition of several local feed ingredients and its apparent protein digestibility coefficient for humpback grouper, Cromileptes altivelis. By: Asda Laining and Rachmansyah

\begin{abstract}
Analysis on chemical composition of several local feed ingredients and determination of its apparent protein digestibility coefficients for humpback grouper, Cromileptes altivelis were carried out in order to obtain basic information on the quality to be used as feed ingredients for fish culture. Test ingredients were animal sources such as sardiness fish meal, commercial fish meal (TAS Companny), shrimp head meal, blood meal, blood silage using both formic and propionic acids, as well as plant sources namely soybean meal, palm oil cake, and rice bran. Protein, lipid, and energy content of animal sources ranged $44.7-87.2 \%, 0.2-9.9 \%$, and $2,500-5,333 \mathrm{cal} / \mathrm{g} \mathrm{re}$ spectively, while of plant sources ranged $10.6-41.0 \%, 11.9-18.4 \%$ and $3,141-4,310 \mathrm{cal} / \mathrm{g}$, respectively. Essential amino acids of blood meal increased through acid preservation using both $3 \%$ propionic acid and 3\% formic acid. Apparent dry matter and protein digestibility coefficients (\%) for those local ingredients were, respectively: shrimp head meal 58.5 and $78.01 \%$, soybean meal 54.8 and $67.2 \%$, palm oil cake 45.3 and $80.5 \%$, blood meal 48.1 and $55.2 \%$, blood silage $A$ ( $3 \%$ formic acid) 67.9 and $87.5 \%$, blood silage B (3\% propionic acid) 61.7 and $84.2 \%$, sardiness fish meal 87.2 and $92.5 \%$, commercial fish meal 59.1 and $82.4 \%$, rice bran 22.2 and $59.5 \%$. Based on the present finding, all local feed ingredients are potential to be used in fish diet as protein and lipid sources as well as energy sources.
\end{abstract}

KEYWORDS: feed ingredients, digestibility, humpback grouper

\section{PENDAHULUAN}

Dalam budi daya ikan/udang intensif, pakan merupakan komponen biaya yang cukup mahal hingga mencapai $60 \%-70 \%$ dari biaya operasional. Hal ini disebabkan oleh tingginya harga bahan baku pakan yang sebagian besar diimpor. Salah satu alternatif yang bisa dilakukan untuk menurunkan harga pakan adalah mengurangi atau mengganti bahan baku impor dengan bahan baku lokal yang potensial sebagai bahan substitusi. Beberapa bahan baku lokal yang dapat dijadikan bahan substitusi adalah by-product seperti kepala udang, bungkil kelapa sawit, dedak ataupun bahan limbah seperti darah hewan ternak. Di

\footnotetext{
) Peneliti pada Balai Penelitian Perikanan Pantai, Maros
} 
samping ketersediaan bahan tersebut yang cukup memadai, harganya pun relatif lebih murah (Ahmad, 2000; Hutabarat, 1999).

Beberapa studi mengenai upaya pemanfaatan bahan by-product dan limbah baik pada pakan ternak maupun pada ikan telah dilakukan oleh Kompiang (1982), Djajasewaka et al. (1991), Laining et al. (2001). Pemanfaatan tepung darah sebanyak $10 \%$ dalam pakan tidak mempengaruhi pertumbuhan dan sintasan ikan nila, Oreochromis niloticus (Otubusin, 1987). Ikan rucah yang dibuat silase dapat pula dimanfaatkan sebagai bahan substitusi sumber protein pada pakan ikan kepiat, Puntius schawanefeld (Djajasewaka \& Tahapari, 1996).

Sebagai informasi dasar dalam upaya pemanfaatan bahan baku lokal tersebut terlebih dahulu perlu diketahui kualitas dari masing-masing bahan dengan menganalisis kandungan nutrisinya dan tingkat kecernaan ikan terhadap bahan baku tersebut karena informasi ini sangat penting dalam kegiatan formulasi pakan yang hemat biaya dan ramah lingkungan (Hajen et al., 1993).

Penelitian ini bertujuan untuk mengetahui kualitas beberapa bahan baku lokal yang diperoleh di Sulawesi Selatan melalui analisis komposisi proksimat dan penentuan nilai kecernaannya pada ikan kerapu bebek, Cromileptes altivelis.

\section{BAHAN DAN METODE}

\section{Komposisi kimia}

Beberapa bahan baku pakan yang secara lokal diperoleh di sentra-sentra produksi di Sulawesi Selatan yaitu tepung kedelai, tepung kepala udang, tepung darah, 2 jenis silase darah masing-masing dengan menggunakan asam formiat $3 \%$ dan propionat $3 \%$, tepung ikan tembang, tepung ikan komersial, dedak, dan bungkil kelapa sawit dianalisis proksimat meliputi protein kasar, lemak kasar, air, abu, serat kasar, dan energi. Silase darah dibuat dengan cara darah segar yang diperoleh dari rumah pemotongan hewan dimasukkan dalam kantong plastik dan dikukus sampai menggumpal hingga matang. Setelah dingin, darah masak digiling hingga hancur dan selanjutnya siap untuk dibuat silase. Dua jenis silase darah masak dibuat dengan menggunakan asam formiat $3 \%$ dan asam propionat 3\%. Selanjutnya, masing-masing jenis asam dicampur secara merata dengan darah masak dan dimasukkan ke dalam wadah tertutup dan diinkubasi selama 5 hari. Pada hari ke-5 silase dipanen dan dikeringkan dengan menggunakan oven dengan suhu $60^{\circ} \mathrm{C}$. Silase kemudian digiling menjadi tepung yang halus dan siap untuk dianalisis maupun untuk digunakan pada uji kecernaan.

Semua bahan baku tersebut di atas dianalisis secara duplo. Analisis kadar air dilakukan dengan pengeringan dalam oven pada $110^{\circ} \mathrm{C}$, protein kasar (semi-mikro Kjeldahl), lemak kasar (Soxhlet-ekstraksi dengan petroleoum benzen), serat kasar (Fibretex), abu (pemanasan dengan Muffle-furnace pada $550^{\circ} \mathrm{C}$ ), dan energi (Bomb calorimeter). Analisis asam amino dengan menggunakan amino acid analizer hanya dilakukan pada tepung darah dan 2 jenis silasenya untuk mengetahui komposisi asam amino darah setelah proses fermentasi. Analisis ini dilakukan di Laboratorium Dasar Bersama, Universitas Airlangga, Surabaya.

\section{Nilai Kecernaan}

Bahan baku lokal yang digunakan pada uji kecernaan ini adalah 9 bahan baku yang telah dianalisis komposisi nutrisinya pada kegiatan pertama di atas dengan menggunakan pakan standar sebagai kontrol. Masing-masing bahan baku dibuat pakan dengan mensubstitusi $40 \%$ dari pakan standar untuk bahan hewani dan 30\% untuk bahan nabati (Cho et al., 1982). Pakan standar yang digunakan adalah pakan terbaik dari percobaan sebelumnya (Rachmansyah et al., 2001). Formulasi pakan standar disajikan pada Tabel 1. Sebagai indikator daya cerna ditambahkan kromium oksida $\left(\mathrm{Cr}_{2} \mathrm{O}_{3}\right)$ sebanyak $1 \%$. Pakan dibuat dalam bentuk pelet kering dan diberikan 2 kali sehari secara satiasi pada pukui 08.00 dan 16.00 .

Hewan uji yang digunakan pada percobaan ini adalah ikan kerapu bebek, Cromileptes altivelis hasil pembenihan di Balai Besar Riset Perikanan Budidaya Laut, Gondol, Bali dan telah diadaptasikan selama 1 bulan di keramba jaring apung, di Instalasi KJA, Teluk Labuannge, Barru. Ikan dengan bobot rata-rata $20 \mathrm{~g}$ dipelihara dalam keramba ukuran $1 \times 1 \times 1,2 \mathrm{~m}^{3}$ dengan kepadatan 20 ekor/keramba. Adaptasi pakan uji dilakukan selama 5 hari sebelum pengumpulan feses dilakukan. Pada saat feses akan dikumpulkan, ikan dipindahkan dari keramba ke tank konikal yang telah dilengkapi tabung tempat koleksi feses (Allan et al., 1999). Proses pengumpulan feses dilakukan 2 kali sehari selama 5-7 hari.

Pakan dan feses selanjutnya dianalisis kadar air, protein, energi, dan kromiumnya untuk digunakan dalam perhitungan penentuan koefisien kecernaan. Kadar air dan protein dianalisis sesuai dengan prosedur pada kegiatan 1, sedangkan analisis kromium menggunakan spektrofotometer Shimadzu UV-VIS 2401PC setelah sampel diekstrak dengan asam nitrat dan asam perkhlorik. 
Tabel 1. Formulasi pakan uji (g/kg pakan)

Table 1. Formulation of experimental diet ( $\mathrm{g} / \mathrm{kg}$ diet)

\begin{tabular}{lccc}
\hline \multicolumn{1}{c}{$\begin{array}{c}\text { Bahan (\%) } \\
\text { Ingredient (\%) }\end{array}$} & $\begin{array}{c}\text { Pakan standar } \\
\text { Reference diet }\end{array}$ & $\begin{array}{c}\text { Pakan uji 1 } \\
\text { Test diets 1 }\end{array}$ & $\begin{array}{c}\text { Pakan uji 2 } \\
\text { Test diet 2 }\end{array}$ \\
\hline Tepung ikan (Fish meal) & 570 & 342 & 399 \\
Tepung kedelai (Soybean meal) & 80 & 48 & 56 \\
Wheat gluten & 100 & 60 & 70 \\
Terigu (Wheat flour) & 60 & 36 & 42 \\
Dedak halus (Rice bran) & 80 & 48 & 56 \\
Minyak ikan (Fish oil) & 40 & 24 & 28 \\
Minyak cumi (Squid oil) & 30 & 18 & 21 \\
Vitamin mix & 30 & 18 & 21 \\
Mineral mix & 10 & 7 & 6 \\
Ascorbic acid & 1 & 1 & 1 \\
Bahan uji 1 (Test ingredients 1) & 0 & 400 & 0 \\
Bahan uji 2 (Test ingredients 2) & 0 & 0 & 300 \\
Kromium oksida (Cromium oxide) & 10 & 10 & 10 \\
\hline
\end{tabular}

* Bahan sumber hewani: kepala udang, tepung darah, silase darah dengan asam formiat $3 \%$ atau asam propionat $3 \%$, tepung ikan tembang dan tepung ikan komersial (PT. TAS)

Animal sources: shrimp head meal, blood meal, silage blood meal using formic acid $3 \%$ or propionic acid 3\%, sardines fish meal and commercial fish meal (TAS com)

** Bahan sumber nabati: kedelai, dedak, dan bungkil kelapa sawit

Plant sources: soybean meal, rice bran, and palm oil cake

Perhitungan nilai kecernaan pakan dihitung berdasarkan rumus:

$$
N K_{p}(\%)=\{1-(\mathrm{Ni} / \mathrm{Nf}) \times(\mathrm{lf} \times \mid \mathrm{pi})\}
$$

dengan $\mathrm{NK}_{\mathrm{p}}$ adalah nilai kecernaan; $\mathrm{N}_{\mathrm{p}}$ dan $\mathrm{N}_{\mathrm{t}}$ adalah nutrien (protein) dalam pakan dan feses; $I_{p}$ dan $I_{f}$ adalah indikator dalam pakan dan feses. Sementara untuk penentuan nilai kecernaan dari setiap bahan baku yang diuji dihitung berdasarkan prosedur Foster (1999), dengan rumus:

$$
\text { NKb (\%) }[\text { NKcom }-\{\text { NKst } \times(1-R S)\}] / \text { RS }
$$

dengan $\mathrm{NK}_{\mathrm{com}}$ adalah nilai kecernaan pakan uji (pakan standar + bahan uji); $\mathrm{NK}_{\mathrm{st}}$ adalah nilai kecernaan pakan standar dan RS adalah rasio substitusi (dalam desimal) dari bahan uji. Rasio substitusi, selanjutnya dihitung berdasarkan rumus:

$$
R S=\left(N_{\text {test }} \times R S_{b}\right) /\left[\left(N_{\text {test }} \times S R_{b}\right)+\left\{N_{\text {st }} \times\left(1-S R_{b}\right)\right\}\right]
$$

dengan $\mathrm{N}_{\text {test }}$ adalah persentase nutrien dari bahan uji, $\mathrm{N}_{\mathrm{st}}$ adalah persentase nutrien dari pakan standar dan $\mathrm{SR}_{\mathrm{b}}$ adalah rasio substitusi bahan uji dalam pakan standar (dalam desimal; 0,4 untuk bahan hewani dan 0,3 untuk bahan nabati).

Penentuan nilai kecernaan dari kesembilan bahan baku tersebut dilakukan dalam 3 unit kegiatan karena keterbatasan fasilitas penelitian. Masing-masing unit kegiatan dirancang dengan Bujur Sangkar Latin $4 \times 4$ terdiri atas satu pakan standar dan 3 pakan uji. Data yang diperoleh dianalisis dengan Anova pada rancangan bujur sangkar latin dan uji lanjut dengan Fischer's protected test (Snedecor \& Cochran, 1989) pada $a=5 \%$.

\section{HASIL DAN BAHASAN}

\section{Komposisi nutrisi}

Kadar protein untuk semua bahan baku yang dianalisis relatif tinggi berkisar antara 41,0\%-87,2\% kecuali bungkil kelapa sawit dan dedak masingmasing $10,6 \%$ dan $13,8 \%$ (Tabel 2). Kandungan protein tepung ikan rucah sebesar $65 \%$ cukup potensial sebagai bahan pengganti tepung ikan impor. Tepung kepala udang dan tepung rebon dengan kandungan protein $49,8 \%$ dan $52,6 \%$ dapat dijadikan bahan substitusi tepung ikan sebagai sumber protein. Akan tetapi tingginya kadar abu tepung kepala udang $(25,1 \%)$ perlu dipertimbangkan dalam upaya pemanfaatannya. Cold storage di Sulawesi Selatan 
menghasilkan limbah kepala udang cukup besar yaitu sebesar 2.062 ton bobot kering/tahun (Ahmad et al., 2000). Sedangkan tepung darah sebagai limbah pemotongan hewan, memiliki kadar protein yang tinggi sebesar 84,3\%; tetapi kadar lemaknya sangat rendah hanya sebesar $2,8 \%$. Kadar protein silase darah dengan menggunakan asam formiat 3\% meningkat dari $84,2 \%$ menjadi $87,2 \%$; sedangkan silase dengan asam propionat $3 \%$ proteinnya relatif sama dengan tepung darah. Peningkatan kadar protein ini seiring dengan peningkatan beberapa asam amino khususnya asam amino essensial pada tepung silase darah (lihat Tabel 3). Hasil analisis protein dan lemak tepung darah ini relatif sama dengan hasil yang dilaporkan oleh Tacon (1994) yaitu masing-masing $85,6 \%$ dan $1,0 \%$.

Tabel 3 menunjukkan bahwa proses fermentasi pada pembuatan silase darah dapat meningkatkan kandungan total 14 asam amino tepung darah yang terdeteksi dari $31,88 \%$ masing-masing menjadi $45,55 \%$ (dengan asam propionat 3\%) dan 55,01\% (dengan asam formiat).

Meskipun dedak dan bungkil kelapa sawit memiliki kadar protein yang rendah $(13,8 \%$ dan $10,6 \%)$ dan serat kasar yang relatif tinggi (14,3\% dan $31,8 \%)$; kandungan lemaknya yang cukup tinggi $(11,9 \%$ dan $12,7 \%$ ) dapat digunakan sebagai sumber lemak dan energi pakan. Proses fermentasi diharapkan dapat meningkatkan kualitas dedak dan bungkil kelapa sawit ini, terutama untuk meningkatkan kadar proteinnya.

Secara umum kualitas bahan baku lokal di Sulawesi Selatan ini relatif sama dengan bahan baku lokal yang ditemui di Pulau Jawa sebagaimana yang dilaporkan oleh Hutabarat (1999).

\section{Nilai Kecernaan}

Nilai kecernaan bahan kering dan protein dari pakan dan kesembilan bahan baku lokal disajikan pada Tabel 4, 5, dan 6. Bahan kering dari tepung kepala udang, tepung kedelai, dan bungkil kelapa sawit relatif rendah di bawah $60 \%$ tetapi kecernaan proteinnya relatif tinggi antara $67,2 \%-80,5 \%$ di mana kecernaan tepung kepala udang tidak berbeda nyata $(P>0,05)$ dengan bungkil kelapa sawit (Tabel 4).

Tabel 5 menyajikan nilai kecernaan tepung darah dan 2 produk silasenya. Ternyata substitusi pakan standar dengan tepung darah sebanyak $40 \%$ menurunkan nilai kecernaan proteinnya. Sebaliknya, nilai kecernaan protein tepung darah secara signifikan meningkat setelah diolah menjadi silase dengan menggunakan asam organik. Silase darah dengan asam formiat $3 \%$ dan asam propionat 3\% menghasilkan nilai kecernaan berturut-turut sebesar $87,5 \%$ dan $84,2 \%$.
Tepung ikan rucah memiliki nilai kecernaan tertinggi baik untuk bahan kering maupun proteinnya yaitu $87,2 \%$ dan $92,5 \%$ (Tabel 6 ). Tingkat kecernaan protein tepung ikan komersial juga relatif tinggi $(82,4 \%)$ tetapi kecernaan bahan keringnya rendah hanya 59,1\%. Dari keseluruhan nilai kecernaan bahan baku yang diuji, dedak memiliki nilai kecernaan paling rendah hanya $22,2 \%$ untuk bahan kering dan $59,5 \%$ untuk protein.

Secara umum nilai kecernaan protein dari semua bahan baku tinggi, kecuali tepung darah dan dedak; sedangkan tepung ikan rucah mempunyai nilai kecernaan protein tertinggi yaitu $92,5 \%$. Tepung darah nilai kecernaan proteinnya $55,2 \%$; jauh lebih rendah dari kecernaan protein darah yang disilase. Dengan kata lain, proses fermentasi pada pembuatan silase darah ini mampu meningkatkan nilai kecernaan proteinnya hingga 32,3\%. Mukhopadhyay \& Ray (1999) melaporkan bahwa proses penambahan asam organik pada proses fermentasi tanpa menggunakan mikroba dapat meningkatkan tingkat kecernaan protein biji wijen pada ikan rohu. Hal yang sama dilaporkan juga oleh Vielma \& Lall (1997) bahwa penambahan asam formiat ternyata dapat meningkatkan nilai kecernaan phospor pada ikan trout, Onchorhynchus mykiss.

Lebih tingginya tingkat kecernaan protein tepung silase darah dengan menggunakan asam formiat dibandingkan dengan asam propionat diduga karena lebih tingginya total asam amino yang dihasilkan pada silase dengan asam formiat dibandingkan asam propionat di mana asam amino lebih mudah dicerna dibandingkan protein. Menurut Asgard \& Austreng (1985) nilai kecernaan asam amino lebih tinggi daripada total fraksi $\mathrm{N}$ dalam pakan pada ikan. Selanjutnya dilaporkan bahwa asam amino esensial umumnya lebih mudah diabsorbsi oleh ikan dibandingkan dengan asam amino nonessensial. Hasil yang sama diperoleh pada ikan mas dan pada ikan cod (Lied \& Njaa, 1982).

Beberapa penelitian mengenai uji kecernaan tepung darah telah dilakukan dengan hasil yang cukup bervariasi. Hal ini diduga karena tepung darah yang digunakan berbeda proses pengolahannya (Hajen et al., 1993) maupun metode pengumpulan feses yang digunakan (Satoh et al., 1992; Sullivan \& Reigh, 1995; Williams \& Mc Meniman, 2002).

\section{KESIMPULAN}

Kandungan protein, lemak, dan energi dari bahan baku lokal sumber hewani masing-masing adalah $44,7 \%-87,2 \%$; 0,2\% - 9,9\%; dan $2.500-5.333 \mathrm{kal} /$ g; sedangkan kandungan protein, lemak, dan energi dari bahan baku sumber nabati antara 10,6\%-41,0\%; $11,9 \%-18,4 \%$; dan $3.141-4.310 \mathrm{kal} / \mathrm{g}$. 
Tabel 2. Komposisi nutrisi (\%) beberapa bahan baku pakan lokal di Sulawesi Selatan

Table 2. Chemical composition (\%) of several local feed ingredients available in South Sulawesi

\begin{tabular}{lcccccc}
\hline $\begin{array}{c}\text { Bahan baku } \\
\text { Test ingredients }\end{array}$ & $\begin{array}{c}\text { Kadar air } \\
\text { Moisture }\end{array}$ & $\begin{array}{c}\text { Protein } \\
\text { Protein }\end{array}$ & $\begin{array}{c}\text { Lemak } \\
\text { Llipid }\end{array}$ & $\begin{array}{c}\text { Serat kasar } \\
\text { Fibre }\end{array}$ & $\begin{array}{c}\text { Abu } \\
\text { Ash }\end{array}$ & $\begin{array}{c}\text { Energi (kal/g) } \\
\text { Energy (cal/g) }\end{array}$ \\
\hline $\begin{array}{l}\text { Tepung kepala udang } \\
\text { Shrimp head meal }\end{array}$ & 6.3 & 49.8 & 3.8 & 2 & 25.1 & 3257 \\
$\begin{array}{l}\text { Tepung rebon } \\
\text { Mysid meal }\end{array}$ & 7.3 & 52.6 & 1.1 & 1.8 & 14.7 & 2500 \\
$\begin{array}{l}\text { Tepung ikan tembang } \\
\text { Sardiness fish meal }\end{array}$ & 7.7 & 65.2 & 4.8 & 1.8 & 12.6 & 4146 \\
$\begin{array}{l}\text { Tepung ikan } \\
\text { Commercial fish meal }\end{array}$ & 7.0 & 44.7 & 9.9 & 3.4 & 24.7 & 4242 \\
$\begin{array}{l}\text { Tepung darah } \\
\text { Blood meal }\end{array}$ & 3.2 & 84.3 & 0.2 & 6.2 & 3.6 & 4844 \\
$\begin{array}{l}\text { Silase darah A } \\
\text { Blood silage A }\end{array}$ & 3.5 & 87.2 & 0.2 & 2.7 & 3.4 & 5333 \\
$\begin{array}{l}\text { Silase darah B"* } \\
\text { Blood silage B }\end{array}$ & 3.5 & 84.7 & 0.2 & 4.5 & 3.1 & 5101 \\
$\begin{array}{l}\text { Tepung kedelai } \\
\text { Soybean meal }\end{array}$ & 9.3 & 41 & 18.4 & 7.2 & 6.0 & 4310 \\
$\begin{array}{l}\text { Bungkil kelapa sawit } \\
\text { Palm oil cake } \\
\text { Dedak (Rice bran) }\end{array}$ & 8.3 & 10.6 & 12.7 & 31.8 & 4.4 & 3767 \\
\hline
\end{tabular}

* Silase dengan asam formiat $3 \%$

Silage using formic acid $3 \%$

** Silase dengan asam propionat $3 \%$

Silage using propionic acid $3 \%$

Tabel 3. Komposisi asam amino (\%) tepung darah dan 2 jenis silase darah

Table 3. Amino acids composition (\%) of blood meal and 2 types of blood silage

\begin{tabular}{lccc}
\hline $\begin{array}{c}\text { Jenis asam amino } \\
\text { Kind of amino acids }\end{array}$ & $\begin{array}{c}\text { Tepung darah } \\
\text { Blood meal }\end{array}$ & $\begin{array}{c}\text { Tp silase darah } \text { A }^{*} \\
\text { Blood silage A }\end{array}$ & $\begin{array}{c}\text { Tp silase darah } \mathbf{B}^{*} \\
\text { Blood silage B }\end{array}$ \\
\hline Asam aspartic & 4.10 & 6.14 & 3.22 \\
Glutamic acid & 2.64 & 5.37 & 2.47 \\
Serine & 1.63 & 2.88 & 3.16 \\
Histidine & 1.09 & 3.95 & 3.84 \\
Glysine & 1.14 & 2.13 & 3.10 \\
Threonine & 1.81 & 2.73 & 1.97 \\
Arginine & 1.28 & 1.79 & 2.10 \\
Alanine & 2.58 & 4.43 & 4.67 \\
Tyrosine & 1.83 & 2.81 & 2.02 \\
Methionine & 1.05 & 1.76 & 1.36 \\
Valine & 3.29 & 5.27 & 3.70 \\
Phenilalanine & 4.43 & 5.93 & 4.37 \\
Isoleusine & 1.25 & 2.21 & 2.82 \\
Leusine & 4.74 & 7.60 & 6.72 \\
\hline Total & 31.88 & 55.01 & 45.55 \\
\hline
\end{tabular}

* Lihat Tabel 2 (See Table 2) 
Tabel 4. Nilai kecernaan bahan kering dan protein dari pakan dan bahan baku uji pada unit percobaan 1 Table 4. Apparent digestibility of dry matter and crude protein of diets and test ingredients examined in experiment unit 1

\begin{tabular}{|c|c|c|}
\hline $\begin{array}{l}\text { Pakan dan bahan baku uji } \\
\text { Test diet and ingredients }\end{array}$ & $\begin{array}{l}\text { Bahan kering } \\
\text { Dry matter* }\end{array}$ & $\begin{array}{c}\text { Protein } \\
\text { Crude protein* }\end{array}$ \\
\hline \multicolumn{3}{|l|}{ Pakan (Diet) } \\
\hline Standar (Reference) & $56.9^{\mathrm{a}}$ & $81.6^{a}$ \\
\hline Kepala udang (Shrimp head diet) & $61.8^{a}$ & $80.1^{a}$ \\
\hline Kedelai (Soybean diet) & $56.3^{b}$ & $77.7^{\mathrm{b}}$ \\
\hline Bungkil kelapa sawit (Palm oil cake diet) & $53.6^{c}$ & $81.5^{a}$ \\
\hline \multicolumn{3}{|l|}{ Bahan baku (Test ingredients) } \\
\hline Kepala udang (Shrimp head meal) & $58.5 \pm 3.33^{a}$ & $78.0 \pm 1.32^{b}$ \\
\hline Tepung kedelai (Soybean meal (full-fat)) & $54.8 \pm 2.72^{b}$ & $67.2 \pm 1.29^{c}$ \\
\hline Tp. bungkil kelapa sawit (Palm oil cake meal) & $45.3 \pm 2.37^{c}$ & $80.5 \pm 1.30^{\mathrm{a}}$ \\
\hline
\end{tabular}

* Nilai dalam kolom yang diikuti oleh huruf yang sama tidak berbeda nyata $(P>0,05)$ Value in column followed by the same superscript are not significantly different $(P>0.05)$

Tabel 5. Nilai kecernaan bahan kering dan protein dari pakan dan bahan baku uji pada unit percobaan 2 Table 5. Apparent digestibility of dry matter and crude protein of diets and test ingredients examined in experiment unit 2

\begin{tabular}{lcc}
\hline \multicolumn{1}{c}{$\begin{array}{c}\text { Pakan dan bahan baku uji } \\
\text { Test diet and ingredient }\end{array}$} & $\begin{array}{c}\text { Bahan kering } \\
\text { Dry matter }\end{array}$ & $\begin{array}{c}\text { Protein kasar } \\
\text { Crude protein }\end{array}$ \\
\hline Pakan (Diets) & $56.3^{\mathrm{b}}$ & $86.2^{\mathrm{a}}$ \\
Standar (Reference) & $53.0^{\mathrm{c}}$ & $83.5^{\mathrm{a}}$ \\
Tepung darah (Dried blood diet) & $59.0^{\mathrm{a}}$ & $86.5^{\mathrm{a}}$ \\
Tepung silase darah A (Blood silage A diet) $)^{11}$ & $60.1^{\mathrm{a}}$ & $72.3^{\mathrm{b}}$ \\
Tepung silase darah B (Blood silage B diet) & & \\
\hline Bahan baku (Ingredients) & & \\
Tepung darah (Dried blood meal) & $48.1 \pm 0.85^{\mathrm{c}}$ & $55.2 \pm 1.35^{\mathrm{c}}$ \\
Tepung silase darah A (Blood silage A meal) & $67.9 \pm 1.63^{\mathrm{a}}$ & $87.5 \pm 0.55^{\mathrm{a}}$ \\
Tepung silase darah B (Blood silage B meal) & $61.7 \pm 2.60^{\mathrm{b}}$ & $84.2 \pm 0.69^{\mathrm{b}}$ \\
\hline 11,2Lihat Table 2 & & \\
11,2See Table 2 & &
\end{tabular}

Nilai kecernaan protein dari bahan baku sumber hewani dan nabati cukup tinggi antara $67,2 \%$ - 92,5\%; kecuali tepung darah dan dedak masing-masing $55,2 \%$ dan $59,5 \%$. Nilai kecernaan tepung darah dapat ditingkatkan melalui proses fermentasi.

Berdasarkan komposisi nutrisi dan nilai kecernaannya, bahan baku lokal dapat dimanfaatkan sebagai sumber protein, lemak, maupun energi untuk pakan pembesaran kerapu bebek.

\section{UCAPAN TERIMA KASIH}

Ucapan terima kasih disampaikan kepada Australian Centre for International Agricultural Research atas bantuan dana yang diberikan melalui proyek kerjasama Improved hatchery and grow-out technology for grouper aquaculture in Asia-Pacific Region.

\section{DAFTAR PUSTAKA}

Allan, G.L, S.J. Rowland, S. Parkinson, D.A.J. Stone, and W. Jantrarotai. 1999. Nutrient digestibility for juvenile silver perch Bidyanus bidyanus: development of methods. Aquaculture. 170: 131-145.

Ahmad, T, Rachmansyah, and N.N. Palinggi. 2000. The availability and use of fish feed local ingredients for humpback grouper grow-out. Proceeding of Regional Workshop on Management Strategies for Sustainable Sea Farming and Grouper Aquaculture. NACA, Bangkok, Thailand. 90-102. 
Tabel 6. Nilai kecernaan bahan kering dan protein dari pakan dan bahan baku uji pada unit percobaan 3 Table 6. Apparent digestibility of dry matter and crude protein of diets and test ingredients examined in experiment unit 3

\begin{tabular}{lcc}
\hline \multicolumn{1}{c}{$\begin{array}{c}\text { Pakan dan bahan baku uji } \\
\text { Test diet and ingredients }\end{array}$} & $\begin{array}{c}\text { Bahan kering } \\
\text { Dry matter }\end{array}$ & $\begin{array}{c}\text { Protein kasar } \\
\text { Crude protein }\end{array}$ \\
\hline Pakan (Diets) & & \\
Standar (Reference) & $58.7^{\mathrm{c}}$ & $89.7^{\mathrm{b}}$ \\
Tepung ikan rucah (Trash fish diet) & $70.4^{\mathrm{a}}$ & $91.3^{\mathrm{a}}$ \\
Tp ikan komersial (Commersial fishmeal diet) & $65.9^{\mathrm{b}}$ & $86.8^{\mathrm{c}}$ \\
Tepung Dedak (Rice bran diet) & $48.3^{\mathrm{d}}$ & $86.1^{\mathrm{c}}$ \\
\hline Bahan baku (Ingredients) & & \\
Tepung ikan rucah (Trash fishmeal) & $87.2 \pm 2.53^{\mathrm{a}}$ & $92.5 \pm 1.40^{\mathrm{a}}$ \\
Tp ikan komersial (Commersial fishmeal) & $59.1 \pm 1.23^{\mathrm{b}}$ & $82.4 \pm 1.99^{\mathrm{b}}$ \\
Tepung dedak (Rice bran meal) & $22.2 \pm 1.52^{\mathrm{c}}$ & $59.5 \pm 1.41^{\mathrm{c}}$ \\
\hline *Nilai dalam kolom yang diikuti oleh huruf yang sama tidak berbeda nyata $(P>0,05)$ \\
Value in column followed by the same superscript are not significantly different $(P>0.05)$
\end{tabular}

Asgard, T and E. Austreng. 1985. Dogfish offal, ensiled or prozen, as feed for salmonids. Aquaculture. 49: $289-305$.

Cho, C.Y., S.J. Slinger, and H.S. Bayley. 1982. Bioenergetic of salmonid fishes: Energy intake, expenditure and productivity. Comp. Biochem. Physiol. 73B: $25-$ 41.

Djajasewaka, H., W. Hidayat, dan D. Koryanti. 1991. Pengaruh penggunaan silase darah dan tepung darah sebagai pengganti tepung ikan dalam pakan buatan terhadap pertumbuhan ikan lele (Clarias batrachus). Bull. Penelitian Perikanan Darat 10 (1): $82-88$.

Djajasewaka, H. dan E. Tahapari. 1996. Pemanfaatan limbah pertanian untuk silase sebagai bahan industri pakan ikan. Prosiding Simposium Perikanan Indonesia I. Puslitbangkan, Jakarta No. $40 \mathrm{pp}$.

Forster, L. 1999. A note on the method of calculating digestibility coefficients of nutriens provided by single ingredients to feeds of aquatic animals. Aquaculture Nutrition. 5:143-145.

Hajen, W.E., R.M. Beames, D.A. Higgs, and B.S. Dosanjh. 1993. Digestibility of various feedstuffs by post-juvenile Chinook salmon (Onchorhynchus tshawytscha) in sea water. 1. Validation of technique. Aquaculture, 112: 321-332.

Hutabarat, J. 1999. Suitability of local raw materials for mud crab feed development. In Mud crab aquaculture and biology. ACIAR Proceeding No. 78. ACIAR, Canberra. 79-89.

Kompiang, I.P. 1982. Lemuru Sardinella sp. meal: preparation and nutritional value for broiler. Bulletin Penelitian Perikanan, 2 (1): 83-86.

Laining, A., Rachmansyah, and T. Ahmad. 2001. Shrimp head meal as a substitute to fish meal in grower feed for barramundi cod, Cromileptes altivelis. Aquaculture Asia, Vol. VI No. 2: 31-32.
Lied, E. and L.R. Njaa. 1982. Apparent availability of total nitrogen, protein nitrogen and of individual amino acids in Atlantic cod (Gadus morhua). Fiskeridir. Skr. Ser. Ernaering. 2: 53-62.

Mukhopadhyay, N. and A.K. Ray. 1999. Effect of fermentation on the nutritive value of sesame seed meal in the diets for rohu, Labeo rohita (Hamilton), fingerling. Aquaculture Nutrition. 5: 229-236.

Otubusin, S.A. 1987. Effects of different levels of blood meal in pelleted feeds on tilapia, Oreochromis niloticus, production in floating bamboo net cages. Aquaculture. 65: 263-266.

Rachmansyah, P.R. Pong-Masak, A.Laining, and A.G. Mangawe. 2001. Kebutuhan protein pakan bagi pembesaran ikan kerapu bebek, Cromileptes altivelis. Jurnal Penelitian Perikanan Indonesia, Vol. 7 No. 4: 40-45.

Satoh, S., C.Y. Cho, and T. Watanabe. 1992. Effect of fecal retrieval timing on digestibility of nutrients in rainbow trout diet with Guelp and TUF faeces collection system. Nippon Suisan Gakkaishi, 58: 1123 1127.

Snedecor, G.W. and W.G. Cochran. 1989. Statistical Methods, $8^{\text {th }}$ edition. lowa State University Press, lowa, USA. 503 pp.

Sullivan, J.A. and R.C. Reigh. 1995. Apparent digestibility of selected feedstuffs in diets for hybrid striped bass (Morone saxatilis $x$ Morone chrysops). Aquaculture. 138: 313 - 322 .

Tacon, A. 1994. Feed ingredients for carnivorous fish species alternatives to fishmeal and other fishery resources. FAO Fisheries Circular No. 881. 35pp.

Vielma, J. and S.P. Lall. 1997. Dietary formic acid enhances apparent digestibility of minerals in rainbow trout, Oncorhynchus mykiss (Walbaum). Aquaculture Nutrition. 3: 265-268. 